https://doi.org/10.52058/2786-4952-2021-4(4)-265-281

Рудоман Ольга Анатоліївна кандидат філологічних наук, доцент, доцент кафедри іноземних мов, Хмельницький національний університет, вул. Інститутська, 11, м. Хмельницький, 29016, e-mail: oarudoman @gmail.com, https://orcid.org/0000-0003-4784-3518

Харжевська Ольга Михайлівна кандидат психологічних наук, доцент, доцент кафедри іноземних мов, Хмельницький національний університет, вул. Інститутська, 11, м. Хмельницький, 29016, e-mail: kharzhevska@gmail.com, https://orcid.org/0000-0001-7032-2863

\title{
КРЕАТИВНА МОВНА ДІЯЛЬНІСТЬ ВИКЛАДАЧА ЯК ВАЖЛИВИЙ ФАКТОР ПДВИЩЕННЯ ЕФЕКТИВНОСТІ ВИКЛАДАННЯ ІНОЗЕМНОӤ МОВИ
}

Анотація. У статті досліджується креативна мовна діяльність викладача як один із важливих факторів підвищення ефективності викладання іноземної мови. Проаналізовано трактування сутності категорій «креативність» та «креативне навчання» та досліджено основні характеристики сучасних креативних методів викладання іноземних мов у закладах вищої освіти. Досліджено такі креативні методи викладання іноземних мов у закладах вищої освіти, як: евристичний метод, активні методи, аудіовізуальний метод, лінгво-соціокультурний метод, репродуктивний метод, метод мозкового штурму, проблемно-дослідницький метод, проектний метод, цифровий метод та логічні методи (індуктивний та дедуктивний). Проаналізовано один із найпоширеніших креативних методів - це дидактичні, рольові та ділові ігри для вивчення іноземної мови. Досліджено етапи реалізації техніки рольової гри під час викладання іноземної мови у закладі вищої освіти, які складаються з таких: вибір учасників; підготовка до виконання сценарію; відповідальність учасників; оцінка та коментарі. Охарактеризовано кілька варіантів реалізації рольової гри для вивчення іноземної мови, такі як: конфліктна рольова гра, кооперативна рольова гра, рольова гра за умов дефіциту інформації, рольова гра на основі завдань, ігри-головоломки, гра на увагу та гра в імітацію. Встановлено, що рольова гра на лекціях іноземної мови використовується насамперед для розвитку мовленнєвих навичок. Визначено, що основними функціями рольових ігор є навчальна функція, виховна та творча функції, мотиваційно-стимулююча функція, комунікативна функція та функція програмування. Встановлено, що навчальні ігри як креативний метод викладання іноземної мови сприяє розвитку професійної комунікативної компетентності та творчої активності, яка $є$ важливою рисою характеру, необхідною для фахівця у 
XXI столітті. Відображено важливість розвитку професійної комунікативної компетентності та творчої активності студентів в межах реалізації креативної мовної діяльності викладача як важливого фактору підвищення ефективності викладання іноземної мови вивчення іноземної мови.

Ключові слова: креативні методи викладання, креативне навчання, іноземна мова, студенти, заклади вищої освіти.

Rudoman Olha Anatoliivna Candidate of Philological Sciences, Associate Professor at the Department of Foreign Languages of Khmelnytskyi National University, Instytutska St., 11, Khmelnytskyi, 29016, e-mail: oarudoman@gmail.com, https://orcid.org/0000-0003-4784-3518

Kharzhevska Olha Myhailivna Candidate of Psychological Sciences, Associate Professor at the Department of Foreign Languages of Khmelnytskyi National University, Instytutska St., 11, Khmelnytskyi, 29016, e-mail: kharzhevska@gmail.com, https://orcid.org/0000-0001-7032-2863

\section{CREATIVE LANGUAGE ACTIVITY OF THE TEACHER AS AN IMPORTANT FACTOR IN INCREASING THE EFFICIENCY OF FOREIGN LANGUAGE TEACHING}

Abstract. The academic paper examines the teacher's creative language activity as one of the important factors in increasing the effectiveness of teaching a foreign language. The interpretation of the essence of the categories "creativity" and "creative learning" has been analyzed and the major features of modern creative methods of teaching foreign languages in higher educational institutions have been investigated. The following creative methods of teaching foreign languages in higher educational institutions have been studied, namely: a heuristic method, active methods, an audiovisual method, a linguo-sociocultural method, a reproductive method, a brainstorming method, a problem-research method, a project-based method, a digital method and logical methods (inductive and deductive). Didactic, role-playing and business games for learning a foreign language have been analyzed as one of the most common creative methods. The stages of the technique implementation of role-playing games in the process of teaching a foreign language in a higher educational institution have been investigated, consisting as follows: selection of participants; preparation for script execution; responsibility of the participants; assessment and comments. Several options of the implementation of role-playing games for learning a foreign language are described, namely: a conflict role-playing game, a cooperative role-playing game, a role-playing game with a lack of information, a task-based role-playing game, a puzzle game, a game to boost attention and a simulation game. It has been established that a role-playing game is used in foreign language lectures primarily for the development of speech skills. It has been determined that the basic functions of role-playing games 
are as follows: an educational function, pedagogical and creative functions, a motivational and a stimulating function, a communicative function and a programming function. It has been revealed that educational games as a creative method of teaching a foreign language contribute to the development of professional communicative competence and creative activity, which is an important character trait necessary for a specialist of the XXI century. The importance of the development of professional communicative competence and creative activity of students in the framework of the implementation of the teacher's creative language activity as an important factor in increasing the effectiveness of teaching a foreign language has been outlined.

Keywords: creative teaching methods, creative learning, foreign language, students, higher educational institutions.

Постановка проблеми. У сучасному світі вивчення іноземних мов стало вимогою часу, у зв'язку з розширенням відносин між іншими країнами, їх знання стало необхідністю та виникла потреба у володінні мінімум однією іноземною мовою. В даний час активно збільшується масштаб викладання іноземних мов у закладах вищої освіти. Іноземна мова як засіб розвитку творчої активності студентів займає особливе місце в системі вищої освіти і є суттєвою для розвитку їхнього творчого потенціалу. Класичний стиль навчання з-за сучасних умов $\epsilon$ неефективним, і необхідно сформувати нову освітню парадигму, яка забезпечуватиме пізнавальну активність і самостійне мислення студентів та здатність безперервно навчатися.

Креативність у методиці викладання іноземної мови сьогодні є сучасним поняттям, де творчість - поняття досить відносне, використання якого не обмежується лише питаннями дослідження. Більшість викладачів іноземної мови зазначають, що мовна освіта має бути пов'язана 3 «творчістю», що означає те, що навчальний процес має бути більш креативним, де викладачі повинні використовувати більше «креативних текстів» для навчання, які повинні надихати студентів використовувати іноземну мову більш «творчо».

Для того, щоб мотивувати, викликати інтерес у студентів до предмету, змусити їх використовувати іноземну мову для спілкування, викладачі часто використовують креативні методи, які заохочують студентів до мислення та розвитку творчих здібностей, що допомагає розвивати та відпрацьовувати нові мовні, комунікативні та поведінкові навички у відносно незвичній розмовній обстановці. Креативні методи $є$ найцікавішим способом для студентів, щоб показати, як вони опановують іноземну мову, а для викладача - найбільш підходящий прийом викладання іноземної мови, тому досить актуальним i необхідним у сучасних умовах $є$ огляд креативної мовної діяльності викладача як важливого фактору підвищення ефективності викладання іноземної мови.

Аналіз останніх досліджень і публікацій. Тематику креативної мовної діяльності викладача як важливого фактору підвищення ефективності викладання іноземної мови досліджує значна кількість науковців. Зокрема, 
Журнал«Герспективитаінновації науки»

(Серія«Гедагогіка», Серія «Гиихологія», Серія «Медицинв»

№4(4) 2021

наукові праці А. А. Деркача, Е. А. Янової, Е. В. Базилевича, И. В. Аргатюка, С. Ф. Щербака, Т. Г. Бортникова, Т. И. Галеева, A. G. Sadykova, A. Kazakbaev, G. Murotova, $O$. V. Shelestova присвячені аналізу креативних методів викладання іноземних мов у закладах вищої освіти, які вплинули на генезис становлення майбутніх фахівців як конкурентоспроможних спеціалістів своєї галузі та забезпечення результативної якісної вищої освіти.

Постановка завдання. Метою роботи $є$ дослідження креативної мовної діяльності викладача як важливого фактору підвищення ефективності викладання іноземної мови. Для досягнення мети визначено такі завдання: визначити сутність категорії понять «креативність» та «креативне навчання»; проаналізувати сучасні креативні методи викладання іноземних мов у закладах вищої освіти; в загальних рисах проаналізувати рольову гру як один із основних креативних методів викладання іноземних мов. При проведенні дослідження були використані загальнонаукові й спеціальні методи дослідження, зокрема аналіз і синтез, порівняння, узагальнення, системно-структурний аналіз.

Виклад основного матеріалу дослідження. Основні питання сучасної мовної освіти представляються в змісті навчання, методах і засобах навчання. Дані категорії методики навчання іноземним мовам в інноваційному процесі трансформуються, як і вся система освіти. Сучасна методична наука $є$ комплексною наукою, що включає в себе лінгводидактику i методику навчання іноземним мовам. Лінгводидактика виступає в якості методологічного аспекту теорії навчання іноземної мови, та являється наукою, що вивчає і формує загальні закономірності способів засвоєння іншомовних знань, навичок і умінь [1, с. 252-254]. Методика навчання іноземної мови розглядає загальні положення, що стосуються процесу передачі іншомовних навичок, знань, умінь. Об'єктом методики виступає процес навчання іноземної мови або процес засвоєння студентами змісту освіти 3 іноземної мови в конкретних умовах навчання [2, с. 54].

Вивчення іноземної мови являється не таким складним процесом, як нам здається, головне - вибрати найпростіший метод вивчення іноземної мови. Старі методи, що застосовуються у більшості навчальних закладів, застарілі, і сьогодні вивчення мови більше залежить від того, хто навчається, ніж від викладача. Найголовніше для вивчення мови - це мотивація, як i в кожній сфері життя [3, с. 773].

На думку вітчизняних та зарубіжних викладачів у сучасному світі необхідно забезпечувати креативний підхід у навчанні іноземної мови. Креативний підхід повинен включати креативний процес і креативне середовище, які сприяють емоційно-психологічній захищеності та комфорту студентів, що веде до реалізації їх творчих можливостей, сприяє розвитку інтелектуальної діяльності, впливає на позитивний емоційний стан та розвиває ініціативу [4, с. 69].

Креативність - це здатність людини розвивати ідеї з метою вирішення проблем та використання можливостей [5, с. 56]. Дослідники зазначають, що «креативні люди творчі в основному не через якусь конкретну вроджену рису, а 
скоріше через ставлення до життя: вони зазвичай реагують на проблеми свіжими та новими способами, а не бездумно й автоматично» [6].

Міллер А. розглядає креативність як здатність, яка «сприяє глибшому навчанню, формує впевненість і формує студента, готового до професійної діяльності» [7].

Креативне навчання - це організація такої творчої роботи, в результаті якої суб'єктам навчальної діяльності стає можливим формування нових творчих продуктів, що відрізняються новизною та оригінальним рішенням, які здатні задовольнити потреби людини в самоосвіті, саморозвитку та творчому самовираженні.

Основним завданням креативного навчання $є$ розкриття творчого потенціалу та трансформація особистості в активній та творчій людині, адже для навчання в університеті - це набуття студентом власної індивідуальності. Для цього необхідно навчити студентів самостійно мислити, мати власну точку зору, вміти обгрунтовувати та відстоювати ії в дискусії, приймати нестандартні рішення, демонструвати вміння та бажання застосовувати творчі якості на практиці» [8].

Розвиток творчості в студентів у процесі навчання іноземних мов базується на теорії поступового вдосконалення творчої розумової діяльності під час навчання. Перший етап зосереджується на свідомому творчому управлінні студентами навчальним процесом. Другий етап спонукає до творчого мислення та саморозвитку, оскільки студент повинен сам вирішити проблему, знайти новий спосіб дій, де студенти орієнтуються на евристичний та творчий рівень пізнавальної діяльності.

Метою розвитку творчої особистості студентів у процесі вивчення іноземної мови ставить такі завдання:

1) стимулювання пізнавальної активності студентів та їх прагнення до самовдосконалення;

2) надання студентам методів і прийомів рефлексивної творчої діяльності;

3) розвиток креативного мислення студентів;

4) засвоєння студентами нових знань та їх творче застосування.

Структурними компонентами творчої діяльності студентів є мотиваційний, пізнавальний та поведінковий. Мотиваційний компонент у структурі творчої діяльності характеризується системою домінуючих мотивів, що виражають свідоме ставлення до цінностей і цілей майбутньої професійної діяльності. Пізнавальний компонент у структурі творчої діяльності проявляється в пізнавальній діяльності. Це дозволяє виділити знання та вміння як критеріальний показник їх сформованості. Поведінковий компонент характеризується практичним, дієвим аспектом творчості. Вона спрямована на цілісне самовизначення та самовираження студентів у навчальній та професійній діяльності.

Функціональними компонентами розвитку творчої діяльності студентів $\epsilon$ гностична, проектна, структурна, організаційна та комунікативна. Необхідно 
Журнал«Герспективитаінновації науки»

(Серія«Гедагогіка», Серія«Гцихологія», Серія«Медицинв»

№4(4) 2021

виділити вміння щодо кожного із компонентів, які повинні формуватися в процесі активної пізнавальної діяльності студентів у процесі вивчення іноземної мови. Ефективним засобом формування особистості може стати вивчення іноземної мови, оскільки студенти набувають уміння аналізувати ситуації та розглядати мовні явища, узагальнювати, спеціалізуватися, вказувати необхідні й достатні умови, визначати поняття, здійснювати судження, знаходити шляхи вирішення навчальних завдань. Все це сприяє розвитку навичок монологічного та діалогічного мовлення та розвитку таких показників прогресу мислення, як порядок, точність, чіткість, стислість, обгрунтованість, послідовність.

Розвиток творчої активності студентів має здійснюватися в усі роки навчання іноземної мови. Поступове набуття досвіду творчої діяльності зумовлює відмінності методів і прийомів, організуючи та забезпечуючи його засвоєння [9].

За усю історію людства було розроблено значну кількість різних освітніх методик для викладання іноземної мови (див. рис. 1). Спочатку всі способи навчання іноземним мовам запозичувалися з програм, розроблених для навчання так званих «мертвих мов» - латинської та грецької мови, в рамках яких практично весь освітній процес зводився до читання і перекладу.

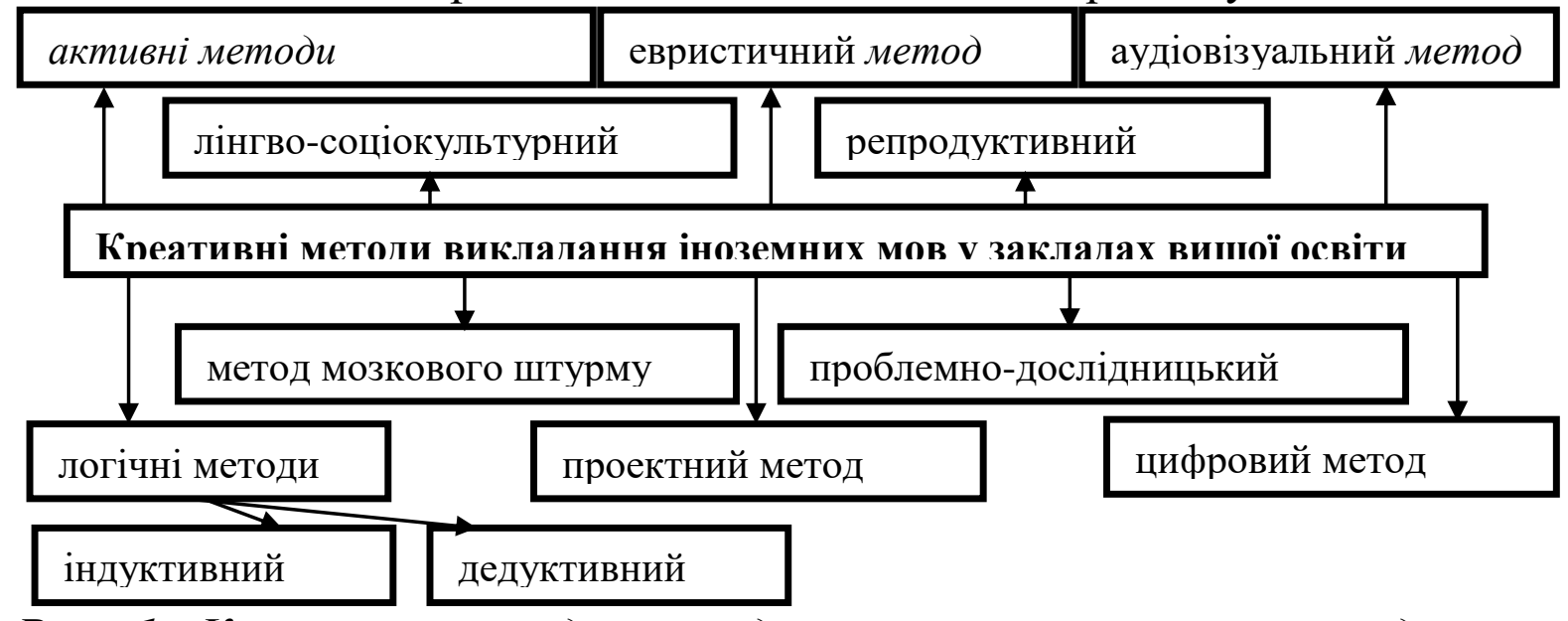
освіти

Рис. 1. Креативні методи викладання іноземних мов у закладах вищзої

Примітки: сформовано автором на основі джерел: [3, с.773; 11, с. 23-24; 12 , c. $178 ; 13$, c. 8$]$.

Розглянемо методи, які використовуються у креативній мовній діяльності викладача при викладанні іноземної мови. Аудіовізуальний метод полягає в тому, що весь новий матеріал сприймається студентом впродовж тривалого часу тільки на слух «аудіо», а його значення розкривається за допомогою зорової невербальної наочності - діапозитивів, діафільмів, кінофільмів. Аудіовізуальний метод доцільний в багатонаціональній аудиторії в країні мови, що вивчається, коли заняття підкріплюються повсякденною практикою спілкування 3 носіями мови, а метою є оволодіння розмовною мовою. Серед недоліків цього методу 
необхідно відзначити негативні наслідки повного виключення рідної мови, які можуть мати місце, а також великі труднощі, які виникають в процесі розкриття значень певних мовних явищ, зокрема, слів, що мають абстрактне значення, фразеологізмів, за допомогою засобів невербальної наочності [10, с. 23-24].

Репродуктивні методи в основному використовуються для того, щоб студенти швидше i точніше запам'ятовували навчальний матеріал та легше виявляли типові недоліки знань. Репродуктивні методи особливо ефективні, коли зміст навчального матеріалу іноземної мови $є$ інформативним та складним i вимагає нових знань. Репродуктивний характер мислення передбачає, що навчальна інформація, передана викладачем чи іншим джерелом є більш активною і запам'ятовуючою. Репродуктивна практика відрізняється тим, що під час цієї роботи студентів часто можна розмістити евристично або частково дослідницьким чином, щоб збільшити їх активність. Студенти отримають можливість поміркувати над деяким матеріалом, який вивчається під час опису нової теми. Викладач ставить короткі запитання і намагається знайти відповіді на них у присутності студентів [3, с. 774].

Однією 3 найбільш всеосяжних методик викладання іноземних мов є лінгво-соціокультурна методика, яка включає два аспекти спілкування - мовне i міжкультурне. За цієї методики мова виступає в ролі дзеркала, в якому відображаються культура і історія народу, умови його життя, традиції, побут, повсякденна поведінка, творчість, географія, клімат. Акцент в навчальних програмах робиться не стільки на правильності мови, скільки на їі змістовності i комунікативному рівні. Мета вивчення мови за допомогою цього методу розуміння співрозмовника, формування сприйняття на інтуїтивному рівні [10, с. 23-24].

Основним методом навчання креативності є проблемно-дослідницький, де сутність методу обумовлена його функціями. По-перше, організовує творче засвоєння знань, тобто вчить застосовувати знання для розв'язування задач і в результаті цього розв'язування отримувати нові знання. По-друге, забезпечує оволодіння методами наукового дослідження в процесі застосування даного методу. По-третє, даний метод сприяє формуванню інтересу та потреби у творчій діяльності [9].

Процес вивчення нової теми представляє проблемно-дослідницький метод подання вивченого матеріалу як проблеми, а не презентації студентам. Висновки, які потрібно зробити під час лекції, робить студент, а не викладач. Кожен студент намагається вирішити проблему індивідуально та висловлює власні ідеї. Дискусії обговорюватимуться та керуватимуться викладачем. Проблемнодослідницький метод активізує пізнавальну діяльність студентів, навчає самостійності, творчості, підвищує їх інтерес до навчання та сприяє підвищенню розвитку їхньої особистості. Цей метод допомагає поглибити знання та повинен забезпечити ретельний аналіз розглянутої проблеми та рівня когнітивного мислення. Студенти повинні мати добре відому базу даних для аналізу обраної 
Журнал«Герспективита інновації наукиљ

(Серія «Гедагогіка», Серія «Гтихологія», Серія «Медицина»

№4(4) 2021

теми, тому для застосування цього методу вони будуть озброєні вибірковою інформацією. Останнім часом особлива увага приділяється застосуванню проблемно-дослідницького методу [3, с. 774].

Компонентне засвоєння досвіду творчої діяльності забезпечується евристичним методом. Найбільш виразною формою цього методу є евристична бесіда. Викладач керує пошуком теми, послідовно ставить завдання, створює конфлікти, вибудовує етапи бесіди, а студенти самостійно шукають вирішення проблемних частин, що виникають на кожному етапі бесіди. Неможливо оволодіти творчою діяльністю без фази часткового розгляду теми для бесіди. Процес оволодіння досвідом творчої діяльності складний і довготривалий, тому студентам важливо бачити перспективу майбутнього, певний стандарт культури мислення, до якого вони можуть і повинні прагнути [9]. Отже, евристичні методи дозволяють студентам частково брати участь у розумінні нової теми [3, с. 774$]$.

Значна чисельність викладачів у процесі викладання іноземної мови звертаються до проектної методології як до одного із сучасних продуктивних творчих підходів, що успішно реалізує основні цілі викладання іноземної мови у формуванні в студентів необхідних комунікативних та мовленнєвих умінь та навичок, які дозволять їм спілкуватися іноземною мовою. Технології проектування досить ефективно використовуються на вищому рівні освіти, оскільки вони дозволяють органічно інтегрувати знання студентів 3 різних галузей при вирішенні однієї проблеми, дають змогу застосовувати отримані знання на практиці, генеруючи нові ідеї, сприяти розвитку комунікативної компетентності, як однієї 3 головних цілей викладання іноземної мови $[11$, с. 178$]$.

Проектний метод спрямований на пошук шляхів розвитку активного самостійного мислення студента та вміння застосовувати знання на практиці. Таким чином, правильний вибір змісту, форм і методів стимулює реалізацію розвивального характеру навчання; сприяє формуванню творчих умінь, що дає можливість розвивати в студентів креативність у процесі вивчення іноземної мови. Викладачі пропонують студентам нестандартні мовні ситуації, такі як пошук відповідних еквівалентів, синонімів, антонімів, творчий переклад тексту, написання рефератів, розв’язування задач та інші креативні завдання [9].

Навчальний процес також включає активні методи: проведення змагань, олімпіад, вікторин, прес-конференцій, тощо. Приклади даних методів: проведення конкурсу на кращого читача, виявлення правильної вимови та загальної виразності мовлення; конкурс на кращого синхронного перекладача, що дає змогу визначити розуміння слухання; конкурс на найкращого перекладача-референта виявляє здатність розуміти текст під час читання іноземною мовою; конкурс на кращого казкаря дає можливість виявити здатність будувати послідовне твердження; конкурс на найкращого співрозмовника виявляє вміння вести діалог, обмінюватися репліками [11, с. 178].

Вивчення іноземної мови за допомогою мобільних пристроїв, як правило, 
забезпечує позитивні ефекти, оскільки цей метод навчання в більшості випадків використовується для вивчення лексики, інтегрованого навчання, аудіювання, мовленнєвих навичок та читання. Даний метод найменш використовується для розвитку письма, граматичних навичок та вимови. Це свідчить про особливості викладання іноземних мов: як правило, студенти витрачають багато часу на вивчення слів, набуття навичок розмови, тому інтерактивні методи викладання $\epsilon$ найбільш придатними в цих аспектах. Необхідність розмовної комунікації в багатомовному середовищі також призвела до високого рівня використання інтерактивних методів. Набуття навичок письма стає все більш складним процесом через низьку поширеність віртуальних клавіатур на мобільних пристроях [12, с. 8].

Логічні методи викладання іноземних мов можуть бути двох типів: індуктивний та дедуктивний. Останнім часом попит на дедуктивне навчання зріс, але без формулювання індуктивних способів мислення не лише природничі та наукові, а й загальні трудові практики не можуть сподіватися на успіх. Використання індуктивних чи дедуктивних методів означає, що вибір переходу від конкретної логіки до загальної розкриває зміст навчальної дисципліни, що вивчається [3, с. 774].

Використання методів активного навчання сприяє розвитку творчості в процесі вивчення іноземної мови. Метод мозкового штурму здійснюється шляхом використання ефектів групової діяльності, групового мислення, спонтанних гіпотез, що сприяє збільшенню кількості генерованих ідей, що дозволяє виробити точки зору інших учасників i, отже, розвивати творчу активність студентів [9]. При застосуванні методу «мозкового штурму», пропонуємо використовувати принципи, розроблені А. Ф. Осборном, а саме: генерування ідей, що сприяють творчому вирішенню проблем; використання ефектів групової діяльності, групового мислення, групової динаміки, методів асоціації, спонтанності, гіпотез, суджень, що сприяє збільшенню кількості генерованих ідей. Метод «мозкового штурму» сприяє розвитку ідей інших учасників навчального процесу, в такий спосіб, надаючи різноманітні точки зору на ту саму проблему [13].

Найпоширеніший із креативних методів - це дидактичні ігри, які являються колективною, цілеспрямованою навчальною діяльністю, коли кожен учасник i команда в цілому об’єднуються для вирішення головної проблеми та орієнтують свою поведінку на перемогу. Гру, організовану з навчальною метою, можна назвати навчальною грою. В умовах підготовки кваліфікованих робітників та спеціалістів широко використовуються ділові ігри. Їх мета - сформувати та відпрацювати конкретні вміння діяти у чітко визначених ситуаціях. Студенти вчаться швидко аналізувати задані умови виробництва, приймати оптимальні рішення та вирішувати економічні проблеми [11, с. 178].

Рольова гра - це сильний мотиваційний метод, який задовольняє потреби студентів у новизні вивченого матеріалу та різноманітності вправ. У процесі 
Журнал«Герспективитаінновації науки»

(Серія «Гедагогіка», Серія«ГЕихологія», Серія«Медицин»»

№4(4) 2021

рольової гри у пам’яті відбувається закріплення мовних явищ, зростає інтерес та активність студентів. Рольова гра являється умовним відтворенням їі учасниками реальної практичної діяльності, що створює умови реального спілкування. Ефективність навчання обумовлена насамперед підвищенням мотивації та інтересу до предмету. Як модель міжособистісного спілкування, рольова гра - це потреба у спілкуванні, яка стимулює інтерес до участі в діалозі іноземною мовою [14].

Техніка рольової гри дозволяє вивчити іноземну мову не тільки інтелектуально, а й емоційно. Для того, щоб будь-яка рольова гра була якісно організованою, необхідно виконати низку етапів (див. рис. 2).

\begin{tabular}{|c|}
\hline Етапи реалізації техніки рольової гри \\
\hline $\begin{array}{l}\text { 1. Вибір учасників. } \\
\text { Рольова гра розпочинається з відбору учасників, кількість яких залежить від } \\
\text { теми та обсягу, який викладач хоче надати студентам. Учасники повинні бути } \\
\text { поінформовані про представлену ситуацію, а також про роль, яку вони будуть } \\
\text { виконувати (видаються чітко прописані методичні рекомендації, щоб у студентів не } \\
\text { виникало сумнівів, які могли б утримати їх від належного відображення призначеної }\end{array}$ \\
\hline $\begin{array}{l}\text { 2. Підготовка до виконання сценарію. } \\
\text { Відібрані учасники повинні вийти } 3 \text { аудиторії, щоб підготуватися до } \\
\text { виконання ролі та вступити у відповідний характер персонажа, поміркувавши про те, } \\
\text { що вони можуть сказати і як вони буде звертатися до інших виконавців. Сценарій } \\
\text { залежно від теми рольової гри та ії концепції, може варіюватися від дуже } \\
\text { реалістичної ситуації, такої як купівля продуктів до вигаданих обстановок, як і } \\
\text { середньовічні вечірки. Для створення кращої атмосфери, деякі ресурси можуть бути } \\
\text { корисними, наприклад гасла, вивіски, аксесуари тощо, які викладач вибирає беручи }\end{array}$ \\
\hline $\begin{array}{l}\text { 3. Bidnoвidaльність учасників. } \\
\text { Перед тим, як студенти почнуть виконувати свою роль, викладач повинен } \\
\text { відзначити важливість належного виконання ролі: почуття, аргументи, міркування, } \\
\text { інтереси, ставлення, поведінка, рішення тощо. Після чого студентам дається вказівка } \\
\text { розпочати гру, а глядачів просять мовчати, щоб не переривати виставу. Реалізм } \\
\text { важливий для передачі повідомлення, тому студенти мають не сприймали } \\
\text { драматизацію як жарт, а також слід уникати і надлишку реалізму, який може }\end{array}$ \\
\hline $\begin{array}{l}\text { 4. Оцінка та коментарі. } \\
\text { Основною метою цього етапу є сприяння колективному діалогу з метою } \\
\text { поглиблення дослідження теми (ставлення, аргументи, наслідки тощо). Студентам, } \\
\text { які виконали роль, необхідно надати слово для коментування того, що вони } \\
\text { відчували, як вони оцінюють себе, чому вони діяли так тощо. Критерії оцінювання } \\
\text { слід надати на початку рольової гри, щоб виконавці усвідомлювали аспекти, які вони } \\
\text { повинні враховувати на момент відображення ролі. Наприкінці викладач повинен } \\
\text { висловити загальний коментар щодо виступу, якщо необхідно, можуть бути зроблені } \\
\text { ввічливо окремі зауваження, щоб заохотити студентів до вдосконалення. }\end{array}$ \\
\hline
\end{tabular}

Pис. 2. Етапи реалізації техніки рольової гри

Примітки: сформовано автором на основі джерела: [15, с. 25-27]. 
Викладачі повинні підтримувати гру дійсно реальною та актуальною, намагаючись зберегти ролі гри максимально реалістичними для життя. Джилліан Портер Ладосс у своїй книзі «Рольова гра» відзначив, що завдяки застосуванню рольових ігор при вивченні іноземної мови, яка має прямий «місток» до реалій сучасного життя, готує студентів до повсякденного спілкування в іншомовному середовищі [16].

Рольові ігри допомагають створити психологічну готовність студентів до мовленнєвого спілкування, викликають природну необхідність частого повторення навчального матеріалу, а також активізують прагнення до контакту студентів та викладача. Це створює умови рівності у мовленнєвому партнерстві, руйнує традиційний бар'єр між викладачем та студентом. Рольова гра дає можливість говорити i, таким чином, долати бар'єр невизначеності. Завдяки іграм студенти набувають таких елементів спілкування, як здатність розпочати розмову, утримати іiі або перервати людину, з якою вони розмовляють, якщо це необхідно в певний момент, погодитися з нею або відкинути ії думку. Студенти також розвивають свої навички аудіювання та говоріння, вміння ставити запитання тощо [14].

Будь-яка рольова гра налаштовується на конкретну цільову тему, яка може бути граматичною, соціальною або пов'язаною з лексикою, яка міститься у навчальному змісті. Існує кілька варіантів реалізації рольової гри для вивчення іноземної мови: конфліктна рольова гра, кооперативна рольова гра, рольова гра за умов дефіциту інформації та рольова гра на основі завдань. Складність, яку призначає обрана рольова гра, залежить від викладача 3 урахуванням рівня та навичок студента.

1. Конфліктна рольова гра ставить студентів у таку ситуацію, коли вони повинні відстоювати свою позицію, взявши всі аргументи, щоб спробувати переконати іншу людину поступитися. Будь-коли в житті студенти неминуче стикаються з певним типом конфлікту, тому вміння справлятися з неприємними ситуаціями необхідно для успіху в будь-якому аспекті життя. Коли студенти знаходять правильний спосіб вирішення конфлікту, вони краще підходять для обговорення ситуації, що склалася. Крім того, налаштування, пов'язані 3 конфліктом, свідчать про рівень володіння іноземною мовою під певним тиском і $\epsilon$ доречними для того, щоб студенти набули зрілості в момент виступу та розвинули свою впевненість у зверненні до інших людей, а також допомагають доповідачу зберігати спокій.

2. Кооперативна рольова гра спонукає студентів до спільної роботи в команді, щоб не тільки використовувати зміст сценарію, але й допомагати один одному для досягнення успіху. Студенти, які працюють разом у команді, мають спільну мету, яка дозволяє їм навчитися довіряти іншим для виконання покладеного на них обов'язку. Такі ситуації доречні для побудови міцних стосунків у групі, враховуючи, що кожен член команди або пари можуть надавати допомогу один одному. 
Журнал«Герспективита інновації науки

(Серія«Гедагогіка», Серія «Геихологія», Серія«Медицин»

№4(4) 2021

3. Рольова гра за умов дефіциту інформації змушує студентів заповнити дірки у своїх знаннях, запитуючи іншу людину про необхідну інформацію. Цей вид рольової гри є чудовим способом адаптувати студентів до зустрічей у реальному житті, враховуючи, що люди за своєю природою є запитувачами $\mathrm{i}$ завжди використовують ці засоби для вирішення своїх запитань. Оскільки ці сценарії потребують правдивої та дійсної відповіді від іншого персонажа, студентам дуже легко долучитися до бесіди.

4. Рольова гра на основі завдань вимагає завершення певної діяльності, яка закінчується виконанням обов'язку. Практичні завдання в сценарії корисні та сформовані у відповідності до реальної життєвої ситуації. У такому сценарії процес виконання поставленого завдання вчить студентів важливим навикам: як правильно ставити запитання, як вести переговори та як взаємодіяти з іншими людьми. Цей вид рольової гри, очевидно, підходить для того, щоб допомогти студентам відпрацювати свої знання іноземної мови в реальних ситуаціях, підвищити їхню впевненість у собі та забезпечити їх мовними та соціальними навичками, необхідними для виконання поставленого завдання [15, с. 27-30].

Формування інтелектуальних здібностей в студентів стало основою переходу до побудови системи навчальних ігор, здатних забезпечити ефективне та якісне формування творчої діяльності в процесі вивчення іноземної мови. Серед цих ігор можна виділити ігри-головоломки, симулятори, змагання та інші. Наприклад:

1. «Який звук я мав/ла на увазі?» (гра-головоломка). Один студент називає кілька слів, усі мають однаковий звук, а решта групи намагається відгадати.

2. «Правда - брехня» (гра на увагу). Викладач називає звуки, показуючи відповідні знаки транскрипції, іноді допускаючи помилки. Студенти повинні виявити помилку.

3. «Скоромовка» (гра в імітацію). Студенти намагаються повторити скоромовку за диктором кілька разів поспіль. Корисно змінювати темп, поступово прискорюючи його.

4. Гра «Десять запитань». Хтось із студентів пригадує будь-який іменник. Інші повинні вгадати його, задавши не більше 10 запитань. Хто відгадає слово, стає ведучим гри. Таким чином, на цьому етапі діалектика формування креативного навчального середовища здійснювалася через взаємодію викладача та студентів, що супроводжувалася підвищенням самостійності, кмітливості та вольових здібностей, емоційного переживання та мотиваційної орієнтації на предмет [9].

Основними ознаками всіх рольових ігор є: а) наявність проблеми, що лежить в основі гри; б) наявність певних персонажів / ролей, які мають різне відношення до обговорюваного питання; в) наявність проблемної ситуації, що містить умови для когнітивного конфлікту.

Рольова гра на лекціях іноземної мови використовується насамперед для розвитку мовленнєвих навичок і співвідноситься 3 двома формами мовлення: 
підготовленою та непідготовленою, створюючи передумови для природного переходу від першої до другої, що у свою чергу, передбачає попереднє засвоєння лінгвістичного матеріалу, формування відповідних умінь і навичок, які в кінцевому підсумку дозволяють студентам зосередитися на змістовній стороні своїх комунікативних навичок.

Дослідники розробили певні правила для рольових ігор, а саме: студент повинен вміти поставити себе в ситуацію, яка може виникнути в реальному житті; студент повинен адаптуватися до своєї ролі у запропонованій ситуації, при цьому в одних випадках він може грати сам, а в інших - брати уявну роль; учасники гри повинні зосередитися на використанні одиниць іноземної мови для комунікативних цілей, а не на їх закріпленні.

Можна використовувати індивідуальні, парні та групові тренування під час реалізації рольової гри, які мають самостійне дидактичне значення, дозволяють поєднувати аудиторну та позааудиторну роботу, навчальну та виховну роботу. Рольова гра в парах $є$ найпростішим видом, яку найкраще реалізувати шляхом використання анкет, які студенти повинні заповнити, задаючи один одному запитання. Навчальні ролі сприяють можливості розвитку різних видів мовленнєвої діяльності та забезпечують реалізації основних функцій рольових ігор, які вони можуть виконувати у навчальному процесі (див. рис. 3) [16, с. 58-59].

\section{Основні функції рольових ігор}

1. Рольова гра має великий потенціал мотиваційно-стимулюючого плану. У процесі рольової гри загальний мотиваційний фон закладений у самому сценарії, а конкретна ситуація та роль, яку отримує студент, звужують їі до суб'єктивного мотиву та диктують мовленнєву / немовленнєву поведінку студента.

2. Рольову гру можна розглядати як найточнішу модель спілкування, оскільки вона передбачає імітацію реальності в іï найважливіших рисах. У рольовій грі поняття «спілкування» розкривається у повному обсязі як мовленнєва та немовна поведінка людини за даних обставин.

3. Рольова гра виконує так звану функцію програмування, тобто розширює асоціативну базу в засвоєнні мовного матеріалу.

4. Рольова гра притаманна навчальній функції. Гра допомагає об'єднати колектив, оскільки у виконанні ролей бере участь вся група студентів, які мають взаємодіяти злагоджено, точно враховувати реакції один одного та допомагати один

5. Рольова гра має виховне та творче значення. Студент розвиває артистизм, вміння оволодівати жестами та мовленням. Саме перевтілення в роль допомагає розширити психологічний діапазон для розуміння інших людей.

Рис. 3. Основні функиї рольових ігор

Примітки: сформовано автором на основі джерела: [16, с. 58-59].

У рольовій грі в максимальній мірі реалізується комунікативна функція 
Журнал«Герспективитаінновації науки»

(Серія«Гедагогіка», Серія«Гцихологія», Серія«Медицинв»

№4(4) 2021

мови як засобу спілкування, і більше того, сама сутність іноземної мови. У зв'язку з цим рольову гру можна відзначити як ефективний інструмент у навчанні усного мовлення [17, с. 18]. Рольова гра має великий потенціал з точки зору реалізації практичних, навчальних та виховних завдань, що стоять перед дисципліною «іноземна мова».

Ігрові форми, у тому числі ділові, потенціал яких значно збільшується у разі використання комп'ютерних технологій. Добре організована ділова гра викликає інтерес, який триватиме впродовж усього періоду вивчення іноземної мови. Оскільки найповніше і яскравіше проявляється творчість людини в несподіваних i нетипових ситуаціях. Ділові ігри відображають динаміку майбутньої професійної діяльності, іiі особливості, складність та основні проблеми. Ділові ігри базуються на професійних ситуаціях зі стандартними помилками, які потім аналізуються. Емоційно значущі фрагменти ігрового спілкування, геніальні рішення, елементи раціонального аналізу $\epsilon$ своєрідним сигналом для запам'ятовування отриманої інформації та використання іiі студентами в подальшій кар'єрі. Варто зазначити, що гра перевершує інші засоби навчання, оскільки студенти занурюються в простір своєї майбутньої професії, відчувають задоволення від виконання своїх професійних функцій та набувають досвіду в майбутній фаховій діяльності [9].

Науковці зазначають, що гра здатна забезпечити не тільки індивідуальні, а й парні, групові та колективні форми роботи на практичному занятті, дозволяючи кожному студентові максимально використовувати аудиторний час. Однією 3 таких мотивуючих та ефективних форм організації навчального процесу $\epsilon$ інтелектуальна гра, яка найбільш повно втілює основні показники діяльності: ініціативність, енергійність, інтенсивність, розмах, широту, масштабність результатів, чесність, зацікавленість, допитливість, самостійність, рішучість, цілеспрямованість та творчість. А головне - гра дає змогу успішно реалізувати комунікативну функцію мови. Крім того, для здійснення іншомовної мовленнєвої діяльності необхідно володіти загальними та специфічними інтелектуальними здібностями. Особливості кожного виду мовленнєвої діяльності, а також цілі й завдання навчання та труднощі в оволодінні ними дозволяють відібрати та конкретизувати найважливіші інтелектуальні вміння, необхідні студентам для оволодіння кожним типом мовлення, та обумовити їх готовність до активного вирішення навчальних завдань [18].

Отже, можна зробити висновок, що застосування сучасних методів викладання іноземних мов у закладах вищої освіти, які базуються на креативній мовній діяльності викладача $є$ важливим фактором підвищення ефективності викладання іноземної мови, що сприяє формуванню комунікативної компетентності студентів та забезпеченню успішного працевлаштування після закінчення навчання.

Висновки. На основі проведеного дослідження можна дійти висновку, що вивчення іноземної мови - це складний процес, який вимагає постійного 
оновлення та дослідження. Забезпечення відповідного функціонування галузі освіти розглядається як одне 3 пріоритетних державних завдань, як важливий структурний елемент забезпечення ринку праці професійними фахівцями відповідних галузей. Помилкова ідея для майбутніх фахівців мати лише знання у своїй галузі та покладатися лише на програму, тому в умовах інтенсифікації інтеграційних процесів формування комунікативної компетентності та розвитку творчої активності студентів в межах вивчення іноземної мови набуває все більшої актуальності.

Творча активність особистості розглядається як невід'ємна характеристика прояву потреби в знаннях і прагнення до їх оволодіння, здатності самостійно мислити, знаходити новий творчий підхід до вирішення навчальних завдань. Розвиток творчої активності представлено як цілеспрямований процес організації пізнавальної діяльності студентів, результатом якого $є$ якісна зміна особистості студентів, виявляючись у прагненні до знань, здатності самостійно мислити та знаходити новий підхід до вирішення проблеми. освітніх проблем, у баченні нових викликів у традиційній ситуації, у створенні абсолютно нових рішень, відмінних від відомих раніше. Використання сучасних креативних методів викладання іноземних мов у закладах вищої освіти може призвести до набуття базових взаємозалежних навичок, таких як вільне володіння іноземною мовою та формування комунікативних здібностей. В результаті компетентнісно орієнтованого навчання іноземних мов студент набуває здатності працювати 3 професійно значущим матеріалом іноземної мови, самостійно здобувати нові знання та розвивати особистий творчий потенціал.

Отримані результати дослідження можуть бути використані для вдосконалення навчальної системи шляхом поєднання креативної мовної діяльності викладача з сучасними методами викладання іноземних мов для підвищення ефективності викладання іноземної мови та формування комунікативної компетентності студентів, що дасть змогу покращити поточну якість вищої освіти при підготовці майбутніх фахівців.

\section{Jimepamypa:}

1. Abdýllaev A. Aktýalnye problemy obýchenı1a arabskomý 1azyký. Molodo1 ýcheny1. 2019. №42. pp. 252-254.

2. Kazakbaev A. The problems and methods of teaching foreign languages. The Light of Islam. 2020, Vol. 2020, Iss. 2, Article 8, pp. 51-60. URL: https://uzjournals.edu.uz/iiau/vol2020/ iss2/8 (дата звернення 06.07.2021).

3. Yuldashova U. B. kizi, Bozorova M. S., Mansurova N. A., Ahmedova Z. A. kizi, Shoazizova A. S. qizi. Language teaching methods: theory and practice. Journal of Critical Reviews, 2020, 7 (5), pp. 768-775. URL: doi:10.31838/jcr.07.05.157 (дата звернення 05.11.2021).

4. Галеева Т. И., Янова Е. А. Креативный подход к обучению иностранным языкам студентов-инвалидов - важный фактор повышения их мотивированного интереса к учебе. Особенности формирования мотивации к изучению иностранных языков и культур в условиях инклюзивного высшего образования : Коллективная монография / Под общей редакцией Н.В. Белозерцевой, С.Н. Богатыревой. Москва: Московский государственный гуманитарно- 
экономический университет, 2019. С. 67-85.

5. Барышева Т. А. Психологическая структура креативности (опыт эмпирического исследования). Известия Российского государственного педагогического университета им. А. И. Герцена, 2012, № (145), С. 54-64.

6. Lerner R. M., Steinberg L. The scientific study of adolescent development: Historical and contemporary perspectives. Handbook of adolescent psychology: Individual bases of adolescent development. John Wiley \& Sons Inc. 2009. pp. 3-14. URL: https://doi.org/ 10.1002/9780470479193.adlpsy001002 (дата звернення 05.11.2021).

7. Miller A. Yes, You Can Teach and Assess Creativity! Edutopia. 2013. URL: http://www.edutopia.org/blog/you-canteach-assess-creativity-andrew-miller (дата звернення 05.11.2021).

8. Ostroumova O. F., Nizamieva L. R., Nazarova G. I. The didactic aspect of foreign language creative teaching. Journal of Language and Literature, 2014, Vol. 5(3), pp. 76-82. URL: DOI: 10.7813/j11.2014/5-3/14 (дата звернення 05.11.2021).

9. Sadykova A. G., Shelestova O.V. Creativity development: The role of foreign language learning. 2016, Vol. 11, pp. 8163-8181.

10. Аргатюк И. В., Базилевич Е. В. Современные методы преподавания иностранных языков. Мир языков: ракурс и перспективы: сборник материалов IX Международной науч.практ. Конференции (Минск, 26 апреля 2018 г.): в 6 ч. Ч. 4. Минск: БГУ, 2018. С.22-26.

11. Muratova G., Abraimova N. The use of information-communication technologies and modern methods in teaching a foreign language. Mental Enlightenment Scientific-Methodological Journal. 2020, Vol. 2020, Iss. 2, Article 20. pp. 175-181. URL: https://uzjournals.edu.uz/tziuj/vol2020/iss2/20 (дата звернення 05.11.2021).

12. Larysa O. A., Oksana B. V., Olga T. M., Olena M. I., Tetiana P. D. Interactive methods of teaching foreign languages in higher education institutions. Revista Tempos E Espaços Em Educação, 2020, 13(32), pp. 1-15. URL: https://doi.org/10.20952/revtee.v13i32.14960 (дата звернення 05.11.2021).

13. Osborn A. F. Applied imagination. New York: Scribner, 1957, 522 p.

14. Bobrovnyk S. N. Role-playing game in teaching foreign languages. 2014. URL: http://www.kamts1.kpi.ua/sites/default/files/files/bobrovnyk_role-playing(1).pdf (дата звернення 05.11.2021).

15. Alvarado Camba José D., Velásquez Zúñiga Bianca M. Influence of the role-play technique on the english language oral production. Guayaquil, 2017. 204 p.

16. Porter Ladousse G. Role Play. Oxford University Press. 1987. 181 p.

17. Solieva M. A. Features of role-playing games in teaching a foreign language. Вестник науки и образования, 2020, № 7(85). Часть 2. С. 57-59.

18. Kalimulina O.V. Role-plays in teaching dialogic speech. Foreign languages at school, 2003. № 3. pp. 17-20.

19. Деркач А.А. Педагогическая эвристика: искусство овладения иностранным языком/ А.А. Деркач, С.Ф. Щербак. Москва : Педагогика, 1991. 224 с.

\section{References:}

1. Abdýllaev, A. (2019). Aktýalnye problemy obýchenı1a arabskomý 1azyký. Molodo1 ýcheny1. №42. pp. 252-254 [in English].

2. Kazakbaev, A. (2020). The problems and methods of teaching foreign languages. The Light of Islam Vol. 2020, Iss. 2, Article 8, pp. 51-60. Retrieved from https://uzjournals.edu.uz/iiau/vol2020/iss2/8 [in English].

3. Yuldashova, U. B. kizi, Bozorova, M. S., Mansurova, N. A., Ahmedova, Z. A. kizi, Shoazizova, A. S. qizi. (2020). Language teaching methods: theory and practice. Journal of Critical Reviews, Vol. 7 (5), pp. 768-775. Retrieved from doi:10.31838/jcr.07.05.157 [in English]. 
4. Halieieva, T. I., Yanova, Ye. A. (2019). Kreatyvnyi pidkhid do navchannia inozemnykh mov studentiv-invalidiv - vazhlyvyi chynnyk pidvyshchennia yikh motyvovanoho interesu do navchannia. [Creative approach to teaching foreign languages to students with disabilities - an important factor in increasing their motivated interest in learning]. Osoblyvosti formuvannia motyvatsii do vyvchennia inozemnykh mov ta kultur v umovakh inkliuzyvnoi vyshchoi osvity: Kolektyvna monohrafiia / Za zahalnoiu redaktsiieiu N.V. Bilozertseva, S.M. Bohatyrovoi. Moskva: Moskovskyi derzhavnyi humanitarno-ekonomichnyi universytet, pp. 67-85 [in Russian].

5. Barysheva, T. A. (2012). Psykholohichna struktura kreatyvnosti (dosvid empirychnoho doslidzhennia). [Psychological structure of creativity (experience of empirical research)]. Visti Rosiiskoho derzhavnoho pedahohichnoho universytetu im. A. I. Hertsena, № (145), pp. 54-64 [in Russian].

6. Lerner, R. M., Steinberg, L. (2009). The scientific study of adolescent development: Historical and contemporary perspectives. Handbook of adolescent psychology: Individual bases of adolescent development. John Wiley \& Sons Inc. pp. 3-14. Retrieved from https://doi.org/10.1002/9780470479193.adlpsy001002 [in English].

7. Miller, A. (2013). Yes, You Can Teach and Assess Creativity! Edutopia. Retrieved from http://www.edutopia.org/blog/you-canteach-assess-creativity-andrew-miller [in English].

8. Ostroumova, O. F., Nizamieva, L. R., Nazarova, G. I. (2014). The didactic aspect of foreign language creative teaching. Journal of Language and Literature, Vol. 5(3), pp. 76-82. Retrieved from DOI: 10.7813/j1l.2014/5-3/14 [in English].

9. Sadykova A. G., Shelestova O.V. (2016). Creativity development: The role of foreign language learning, Vol. 11, pp. 8163-8181 [in English].

10. Arhatiuk, I. V., Bazylevych, Ye. V. (2018). Suchasni metody vykladannia inozemnykh mov. [Modern methods of teaching foreign languages]. Svit mov: rakurs ta perspektyvy: zbirka materialiv IX Mizhnarodnoi nauk.-prakt. Konferentsii (Minsk, 26 kvitnia 2018 r.): o 6 hod. Ch. 4. Minsk: BDU, pp. 22-26 [in Russian].

11. Muratova, G., Abraimova, N. (2020). The use of information-communication technologies and modern methods in teaching a foreign language. Mental Enlightenment ScientificMethodological Journal, Vol. 2020, Iss. 2, Article 20. pp. 175-181. Retrieved from https://uzjournals.edu.uz/tziuj/vol2020/iss2/20 [in English].

12. Larysa, O.A., Oksana, B.V., Olga, T.M., Olena, M.I., Tetian, P.D. (2020). Interactive methods of teaching foreign languages in higher education institutions. Revista Tempos E Espaços Em Educação, 13(32), pp. 1-15. Retrieved from https://doi.org/10.20952/revtee.v13i32.14960 [in English].

13. Osborn, A.F. (1957). Applied imagination. New York: Scribner, 522 p. [in English].

14. Bobrovnyk, S.N. (2014). Role-playing game in teaching foreign languages. Retrieved from http://www.kamts1.kpi.ua/sites/default/files/files/bobrovnyk_role-playing(1).pdf [in English].

15. Alvarado, Camba José D., Velásquez, Zúñiga Bianca M. (2017). Influence of the roleplay technique on the english language oral production. Guayaquil, 204 p. [in English].

16. Porter, L.G. (1987). Role Play. Oxford University Press. 181 p. [in English].

17. Solieva, M.A. (2020). Features of role-playing games in teaching a foreign language. Visnyk nauky ta osvity, № 7(85). Chastyna 2. pp. 57-59. [in English].

18. Kalimulina, O.V. (2003). Role-plays in teaching dialogic speech. Foreign languages at school, № 3. pp. 17-20. [in English].

19. Derkach, A.A. (1991). Pedahohichna evrystyka: mystetstvo ovolodinnia inozemnoiu movoiu. [Pedagogical heuristics: the art of mastering a foreign language]/O.O. Derkach, S.F. Shcherbak. Moskva: Pedahohika, 224 s. [in Russian]. 